\title{
Growth and Decline
}

\section{Matthew Andrews}

The great and increasing population of the North of England, and its remoteness from the Universities of Oxford and Cambridge, have long pointed out the expediency of establishing in that part of the kingdom an Institution which should secure to its inhabitants the advantages of a sound yet not expensive academical education. ${ }^{1}$ Durham University Calendar for 1836

\section{Introduction}

Given the strong interest in university reform from 1800 onwards and the number of proposals for new institutions that emerged during the same period, it might be assumed that the story of higher education in the nineteenth century is one of continued growth. The truth is much less consistent.

Far from heralding an era of expansion, England's new institutions founded in the Age of Reform struggled. The expected interest in mod- ern academic studies at a higher level simply did not materialise and the founders of the new universities faced significant recruitment shortfalls that placed their young institutions in jeopardy. There is, then, a stark contrast between the clear ambition which led to the establishment of institutions (remembering also that many more were projected and never founded) and the general failure and near-collapse of these institutions in their early decades.

\section{Student recruitment in the nineteenth century}

Higher education across Europe, including England, did not expand consistently throughout the nineteenth century. ${ }^{3}$ Robert Anderson has shown that universities from Scotland to Russia experienced the same broad trend of growth in the period up to about 1830 (the years following the Napoleonic Wars), followed by stagnation until the mid-1860s and then renewed growth from 1870 until the eve of the First World War. According to one analysis of enrolments, there was even a decline in the rate of admission to English universities between 1821 and 1861 . The number of students enrolling in 1831 was lower than that in 1821 (Fig. 8.1). ${ }^{5}$

The general pace of change accelerated from about 1870 onwards, though Oxford and Cambridge preceded this expansion by a few years with a surge that started in the late 1860s. From about the middle of the century too, the middle classes showed an increasing interest in the growing number of public schools able to prepare their sons for careers in the civil service, the military or the Church. ${ }^{6}$ Owens College, which almost collapsed in the 1850s,

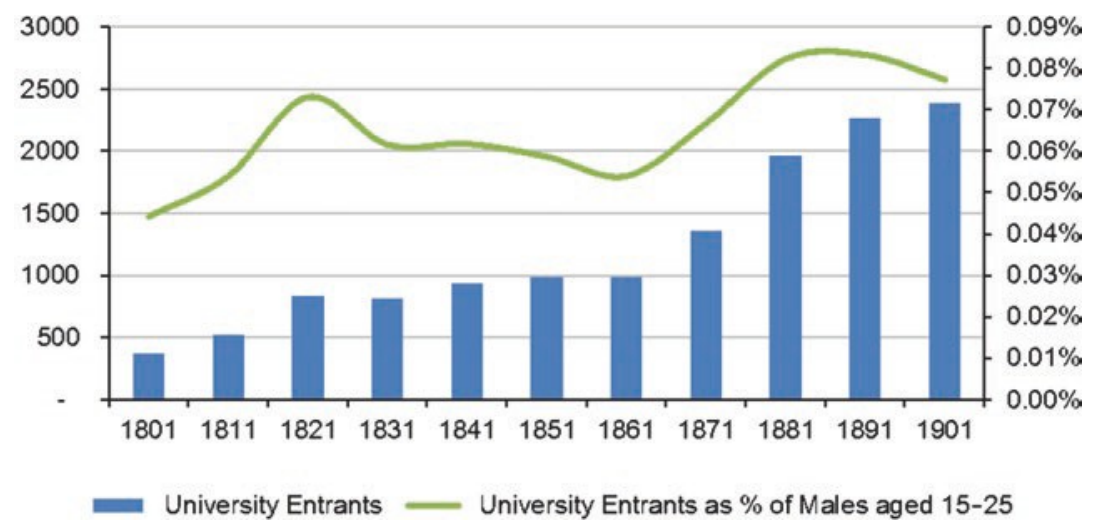

Fig. 8.1 Participation rates in English universities 1801-1901 (male students only) (Source Greenwood, 'University Education’, p. 7)

\footnotetext{
${ }^{1}$ Durham University Calendar 1836, p. 3. This is the opening text of the first full University Calendar, which remained the same until well into the twentieth century.

${ }^{2}$ For example, proposals in Bath, Leeds and Liverpool.

${ }^{3}$ Anderson, European Universities, pp. 119-37.

${ }^{4}$ Anderson, European Universities, pp. 124-26; Reader, Professional Men, pp. 142-45.

${ }^{5}$ M. Greenwood, 'University Education: Its Recent History and Function', Journal of the Royal Statistical Society, 98(2) (1935), pp. 1-33. Greenwood’s figures excluded female students for ease of comparison across the century; he therefore calculated the rate of entry as a proportion of the male population aged 15-25.

${ }^{6}$ Anderson, Universities and Elites, p. 33; Simon, The Two Nations, pp. 302-3, 318-20; and G. Sutherland, 'Secondary Education: The Education of the Middle Classes', in G. Sutherland et al. (eds.), Education (Dublin, 1977), pp. 137-95, at pp. 137-59.

${ }^{7}$ Ward, Victorian Oxford, p. 283.
} 
expanded rapidly in the 1870s. This increase gave the College's leaders sufficient optimism to forecast the enrolment of 2000 students. ${ }^{7}$ This hope proved fanciful, but the available statistics demonstrate that while there had been considerable growth between about 1810 and 1830, the decisive shift in the evolving higher education sector occurred from about 1870 onwards: between 1871 and 1881 alone, there was a 44\% increase in admission to university. This was a trend experienced internationally too, as the universities in various parts of the British Empire experienced growth from the 1870s as part of increasing Victorian globalisation (Fig. 8.2). ${ }^{8}$

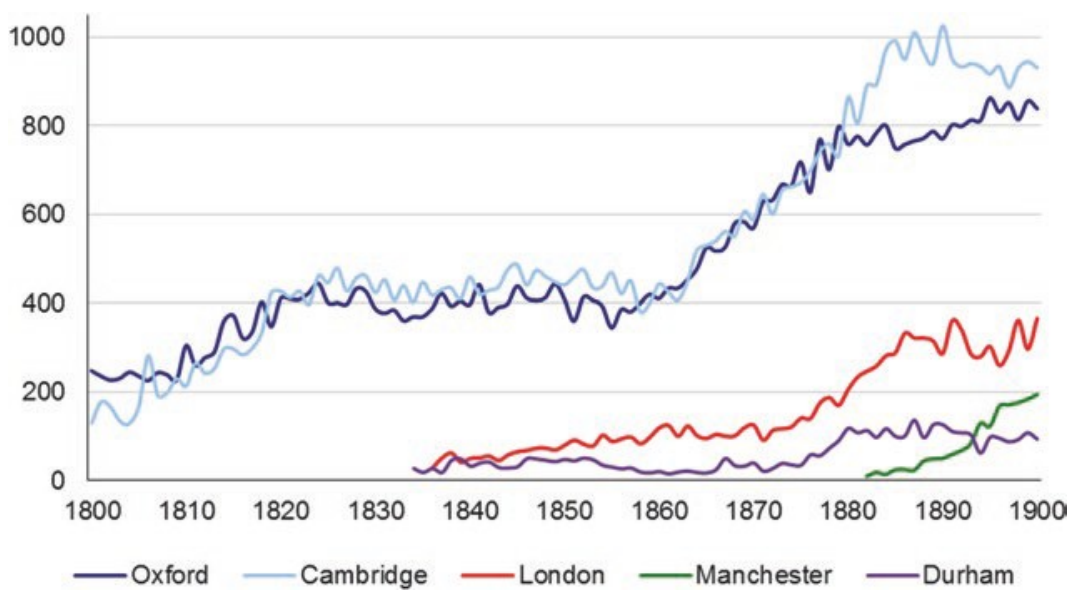

Fig. 8.2 Entrants to English universities 1799-1903 (male students only) (Source Greenwood, 'University Education’, p. 6)

Though the expansion from 1870 onwards marked the start of rapid and persistent growth, one constant throughout the nineteenth century was that Oxford and Cambridge remained not only considerably larger but also one step ahead of their new rivals. Even by 1903, 72\% of all male university students entered Oxford and Cambridge.

These figures tell the bleak story of the significant difficulties that beset all new institutions of higher learning during the nineteenth century. Even London University and King's College, London-institutions normally feted for breaking the Oxbridge duopoly—conspicuously failed to prosper at first. ${ }^{9}$ This is despite the advantage they enjoyed of being based in London with easy access to key facilities and potential students. Both colleges, unlike Durham, were also open to all without religious tests-a key demand of Dissenters and others, who decried being locked out of English higher education — and neither insisted on an expensive mode of residential living. However, by the mid1830s, the decline in the number of students at London University was a matter of public debate. ${ }^{10}$ The institution's financial difficulties were considerable and mounting, even to the extent that 'bailiffs' were reported to have chased 'the Professor of Modern History round the quadrangle' after seizing 'the air-pump, the exhausted receiver, and the galvanic batteries.' ${ }^{11}$ London University, which had spent $£ 2580$ on library books in 1828-1829, sacked the first librarian in 1831 for lack of funds and dropped expenditure to an average of only £51 per year between 1832 and $1875^{12}$

As early as January 1832, Van Mildert confidently asserted that London University was 'manifestly on the decline'. He was not alone in doing so. By February 1833, there were serious suggestions that the institution could not continue 'upon its present footing,. ${ }^{14}$ By 1846, now re-titled University College, the situation was little improved. Brougham bemoaned that 'his anticipations of its success had not been realized, or anything like realized', and he berated his fellow citizens, who despite having complained for 'a century' of the want of a university in London persisted in sending their sons 'to be corrupted at Oxford or Cambridge'. ${ }^{15}$ The early decades of King's College were much the same and by the mid-1850s, 'a general air of poverty and depression brooded over the dingy scene' at the Strand. ${ }^{16}$

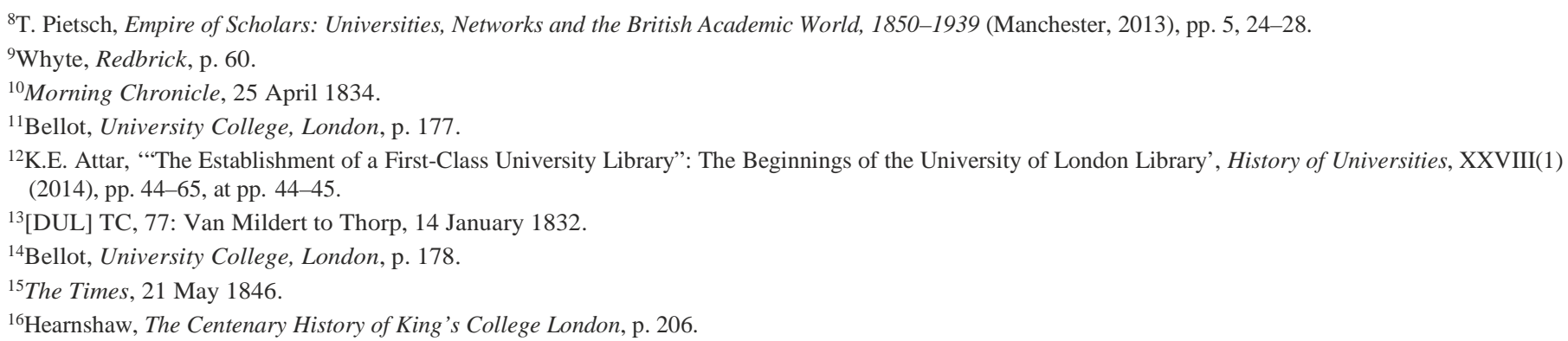


Even by the mid-nineteenth century, new institutions were suffering. ${ }^{17}$ In 1865, Queen's College, Birmingham was declared bankrupt and closed, with its theology department later reopening as a theological college and its medical school merged into rival Sydenham College. ${ }^{18}$ In Manchester, Owens College was in a very dangerous state just a few years after its foundation: the number of ordinary students almost halved from 62 in 1851/52 (the first full year of the College's operation) to 33 in 1856/57. In 1856, the first Principal of Owens College, Alexander Scott, reflected on the College's diminished intake of ordinary students and advised the trustees that it was their 'duty ... to persevere till the value of the college became matter of experience, and a demand was created which did not then exist'. He suggested that the College establish a school to help create a group of potential students; meanwhile, Joseph Greenwood, the Professor of Greek and Latin, suggested that it would have been better if the College had simply been a school in the first place rather than a college at all. Greenwood also held that its unsectarian nature had limited its likely supporters. ${ }^{19}$ In July 1858, the Manchester Guardian called the College a 'mortifying failure', bemoaning that only 'eight years ago' it had been hoped it 'would form the nucleus of a Manchester University'. The newspaper's editorial attributed the difficulties to the curriculum on offer: 'first, the College supplies a kind of education which is not wanted; and, secondly, it does not supply the education which is wanted' ${ }^{20}$ Henry Roscoe, the Professor of Chemistry, described the College at that time as being 'nearly in a state of collapse'.

Back in London, the story of disappointing beginnings continued. The Royal School of Mines, founded in 1851 as the Government School of Mines and of Science Applied to the Arts, was deeply unsuccessful; until 1869, it produced no more than six Associates in any year, and double figures were not reached until $1876 .{ }^{22}$ Suspicious mine owners still distrusted academic theory and failed to show any real interest in the College, just as they had shown no interest in Durham's engineering course in the late 1830s or Wood's proposed college in Newcastle in the 1850s. This slow progress with the development of scientific and technical instruction was amply recorded in the Royal Commission on Scientific Instruction and the Advancement of Science (known as the Devonshire Commission), which undertook its investigations from 1870 to 1875 . While the Commission's report noted some progress in places, including King's and University Colleges in London, Owens College in Manchester and the recently established College of Physical Science in Newcastle, it found grave deficiencies more generally and especially in the old universities and at an elementary level. ${ }^{24}$

\section{Student recruitment at Durham, king's College and University College}

The accepted narrative of higher education development in the nineteenth century could give the impression that recruitment to the new London colleges was buoyant while students eschewed Durham. The reality is more complex and undermines the simple view of how the new universities developed.

The number of students recruited to Durham was at first reasonably promising: after an exceptional response for the first intake, entrants dipped, but then grew throughout most of the 1830s. Students from the north of England were in the majority, accounting for $58 \%$ of those students with a known place of birth over the first decade, with 30

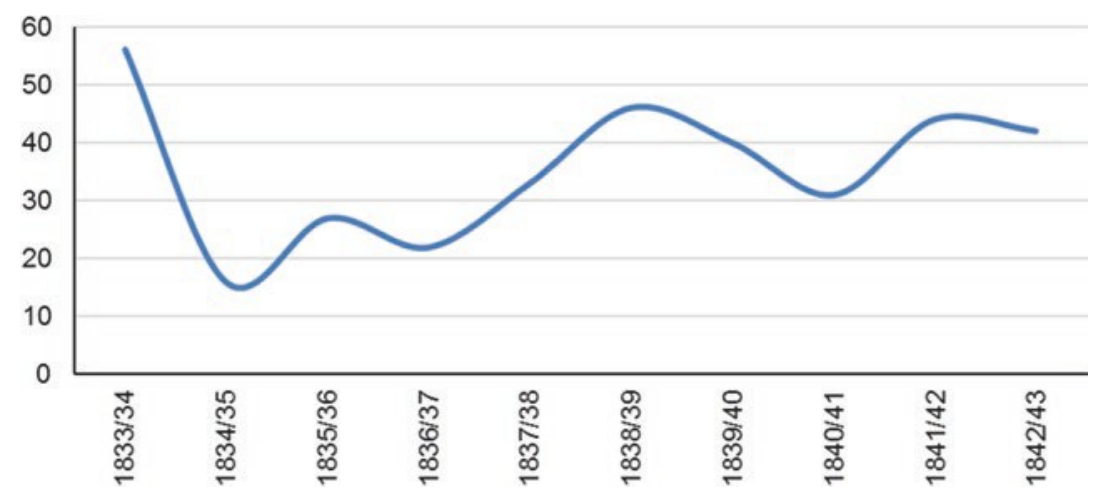

Fig. 8.3 Entrants 1833/34-1842/43 (Durham only, all courses) (Source [DUL] DUR: Admission book 1833-1896)

\footnotetext{
${ }^{17}$ Armytage, Civic Universities, p. 220; Briggs, 'Development in Higher Education’, pp. 95-116, at pp. 110-13.

${ }^{18}$ Whyte, Redbrick, pp. 96-97.

${ }^{19} \mathrm{~J}$. Thompson, The Owens College: Its Foundation and Growth and Its Connection with the Victoria University, Manchester (Manchester, 1886), p. 155.

${ }^{20}$ Manchester Guardian, 9 July 1858.

${ }^{21}$ W.H. Chaloner, The Movement for the Extension of Owens College Manchester 1863-73 (Manchester, 1973$)$, p. 1.

${ }^{22}$ Roderick and Stephens, 'Mining Education in England and Wales', p. 109.

${ }^{23}$ Reader, Professional Men, p. 141.

${ }^{24}$ D.R. Jones, The Origins of Civic Universities: Manchester, Leeds and Liverpool (London, 1988), pp. 38-39; R. MacLeod, 'Scientific and Technical Education', in Sutherland et al. (eds.), Education, pp. 196-225, at pp. 203-10.
} 
coming from the south of England and the remainder from the rest of the UK or overseas. While in most years the Arts course dominated, Theology and, for a while, Civil Engineering admitted significant proportions too (Figs. 8.3 and 8.4).

The student population in Durham grew slowly to a peak of 140 in 1852/53. ${ }^{25}$ This level did not last, however, and there was a significant drop in numbers during the 1850s (Figs. 8.5 and 8.6).

However, Durham's recruitment had started to compare more favour- ably with other new institutions. The number of students studying the General course at King’s College, London, provided a reasonable benchmark for Durham: both institutions were explicitly Anglican foundations, and the General Arts course was like the Durham BA, containing divinity, classics, mathematics and English (though Hearnshaw described the King's course as 'chaotic and aimless'). ${ }^{26}$

While the number of students at King's varied, the Arts course at Durham grew consistently every year throughout the 1840s until 1852/53, when there were more students studying Arts in Durham than were studying General Arts at King's. The decline at both institutions, though starting slightly early at King's, lasted throughout the 1850s. Although recruitment at Durham was relatively poor, it remained stable throughout the late 1840s and the early years of the 1850s (Fig. 8.7).

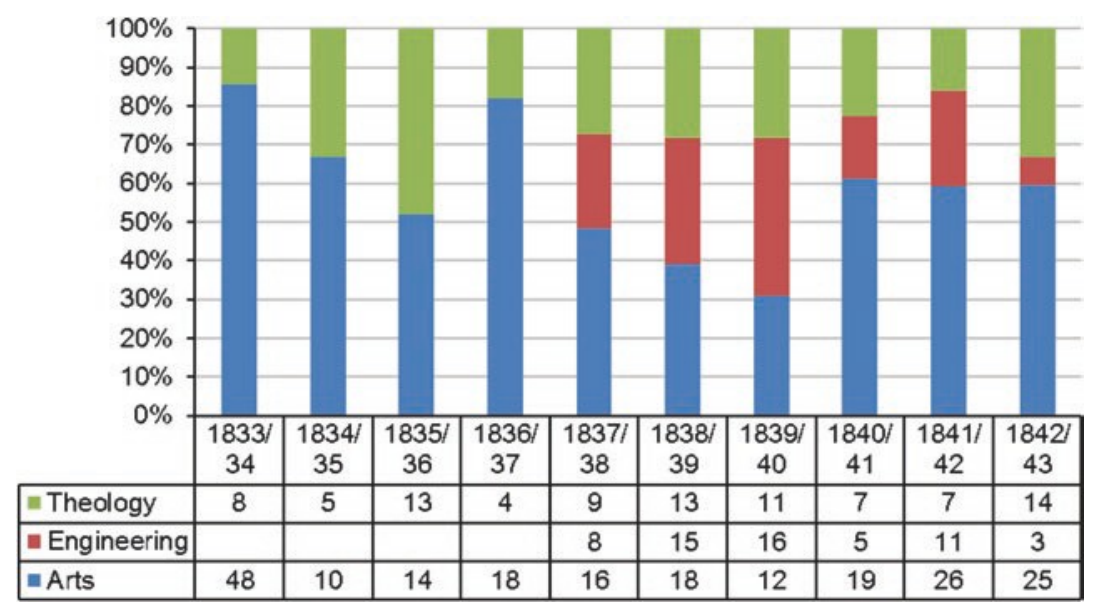

Fig. 8.4 Entrants 1833/34-1842/43 by course (Durham only) (Source [DUL] DUR: Admission book 1833-1896. Two students are omitted from this table as it was not possible to identify the course they entered to study. In addition, many students progressed from one course to a second course, but these continuing students have been omitted)

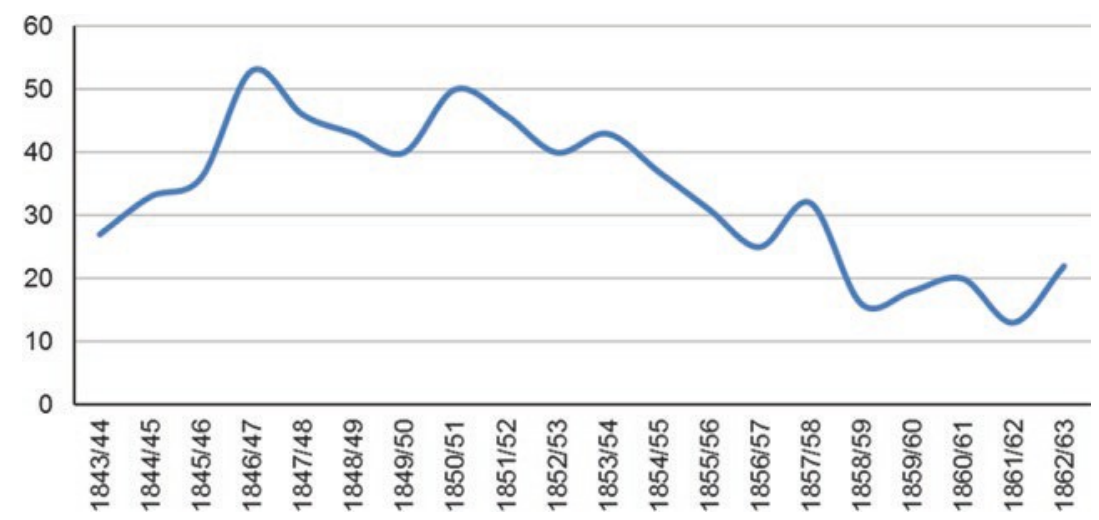

Fig. 8.5 Entrants 1843/44-1862/63 (Durham only, all courses) (Source [DUL] DUR: Admission book 1833-1896)

\footnotetext{
${ }^{25}$ In his evidence to the Commission, Hornby stated that the maximum number of students at any point was 134. Cf. Copy of all Evidence taken by the Durham University Commissioners under the Durham University Act, 1861 (London, 1863), q. 1006, p. 47.

${ }^{26}$ Hearnshaw, King's College London, p. 111.
} 


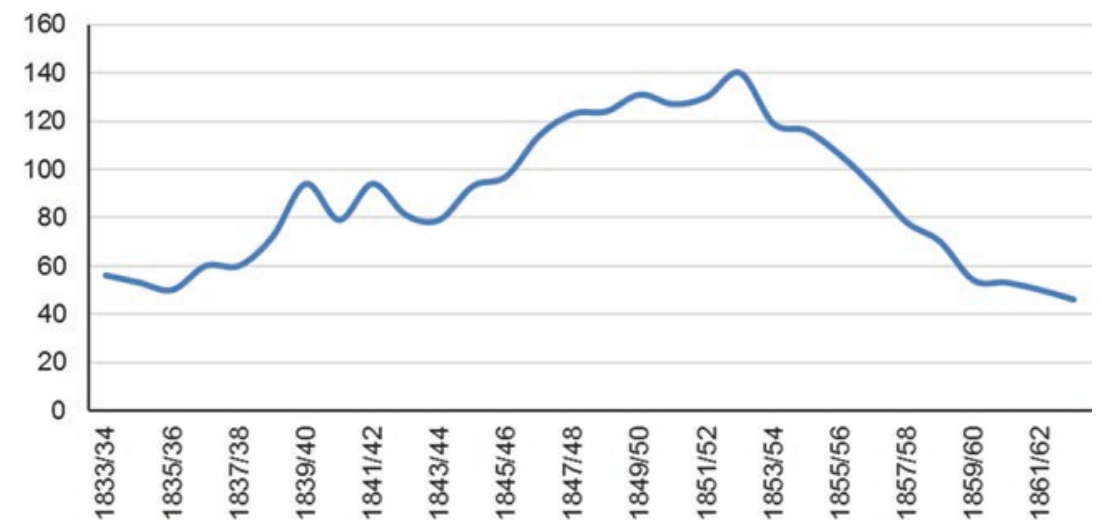

Fig. 8.6 Students 1833/34-1862/63 (Durham only, all courses) (Source As listed in the University Calendar)

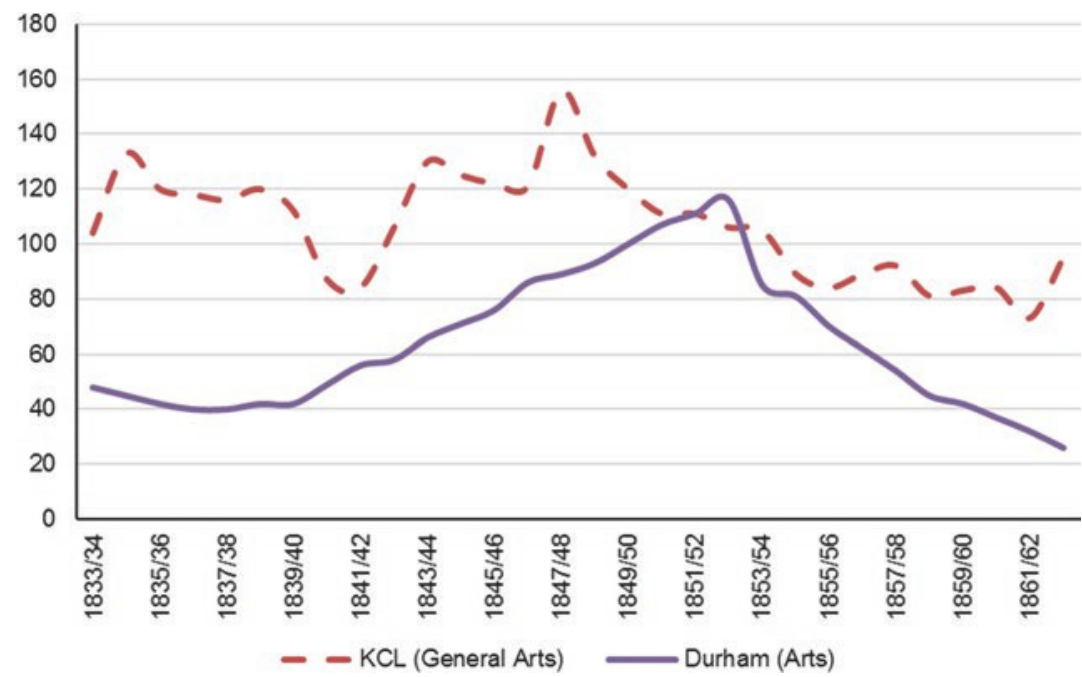

Fig. 8.7 Students 1833/34-1862/63, Durham and King's College, London (Arts course) (Source 'Durham (Arts)' as listed in the University Calendar. 'KCL (General Arts)’ from Hearnshaw, King’s College London)

\section{Developments in the higher education sector from 1860}

The influences behind this lack of progress started to change during the 1860 s and more especially from $1870 .^{27}$ Until the latter part of the century, there was, first, no agreement over what higher education was. The boundaries between secondary and higher education were not well defined in the early nineteenth century and, indeed, the terms secondary education and higher education were not used during the period. At the start of the century, secondary education, as we now understand it, was largely undeveloped in England, save for the limited and often exclusive provision of the grammar and public schools. There were no independent examinations in secondary schools until Oxford and Cambridge established the Local Examinations in 1857-1858, with Durham itself swiftly following in $1858 .^{28}$

For the new post-secondary institutions, this lack of secondary education meant that there were simply insufficient qualified students to fill their new courses. The lack of definition also meant that the boundary with the better secondary schools was blurred. Similar issues persisted in the Scottish university system, with the non-professional education of institutions north of the border being accused of offering little more than the same instruction as could be found in a school. In 1823, for example, the combative Tory journal Blackwood's Edinburgh Magazine carried scathing comments on Glasgow University:

The 'University' of Glasgow is composed of two things; first, a school where boys from twelve years of age, up to sixteen or seventeen, are instructed in the first elements of Classical learning ... and also, in the first elements of Mathematics, Law, Ethics, \&c; and secondly, of an institution in which lectures are delivered on Medicine, Law, and Theology, for the benefit of those of rather riper years. To dream of comparing [the boys at Glasgow] with the boys of Eton, or Westminster, or Winchester, or Harrow ... would be about as absurd, as it would be to compare a Spouting Club in Cheapside with the British House of Commons. ${ }^{29}$

${ }^{27}$ Lowe, 'The Expansion of Higher Education in England'.

${ }^{28}$ J. Roach, Public Examinations in England, 1850-1900 (Cambridge, 1971), pp. 64-76, 89; Whiting, University of Durham, pp. $256-57$.

29،Vindiciae Gaelicae’, Blackwood’s Edinburgh Magazine, 13(72) (January 1823), 
Both King’s College and University College had schools which were at first far more successful than their higher departments. ${ }^{30}$ Both colleges relied significantly on their medical departments and day schools rather than on their general Arts courses for survival. In some respects, the schools of the two London colleges were part of the broader appearance of new secondary schools for the middle classes which accelerated from the 1830s onwards. ${ }^{31}$ However, their existence was also testimony to the lack of qualified candidates for the higher departments and, faced with this shortfall, the colleges took matters into their own hands and founded schools to prepare their own students. ${ }^{32}$ When, in 1856, Alexander Scott suggested that Owens College should establish a school to prepare students for entry to their higher courses, he was following a familiar pattern. Secondary education remained ineffective until the Clarendon Commission of 1864 and the Schools Inquiry Commission of 1867-1868. Even then, the situation was patchy, divided by class, and the school leaving age was not raised to 14 until the Fisher Act of 1918 . $^{33}$ An inadequate supply of suitable students accounted for a large measure of the difficulties of the new institutions. There was also a second impact: initially, an invigorated secondary sector took students away from the universities. ${ }^{34}$

If a lack of qualified students led to difficulties maintaining the intended level of the general courses at the new colleges, it also forced them into the position of being feeders of students into Oxford and Cambridge. This further depressed their status in the slowly developing higher education sector as they were used as springboards to the ancient English universities. The same trend was not uncommon in the Scottish universities, where students might also migrate to Oxford or Cambridge. And when the secondary sector did develop, there was a tendency to encourage students to enter the ancient institutions over the new if possible. The recently founded schools were as concerned about their own prestige as any new college or university and so directed their students to the old universities in order to bolster their own reputations.

To make matters even worse, there was insufficient demand for the graduates the new colleges did produce. The purpose of higher education has perhaps always been a topic of contested debate, but this was especially true during the nineteenth century when universities underwent a radical transformation as they slowly evolved strong connections with the old, new and developing professions. Rather than being established to satisfy a clear demand, therefore, Durham and other new institutions were largely established because of ideals, philosophies and conceptions of higher education. The motivation behind the foundation of King's College, London, for example, was not that London University was an astounding success and stood testament to latent demand, but because it posed a threat and the Establishment of Church and State wished to promote its own institution which would compete with it on equal terms for the same type of students while delivering similar academic content. ${ }^{36}$

However, a pedagogic principle or educational ideal could not give a graduate a job. Even in nineteenth-century England, students wanted to know that the investment in their higher education (which was still expensive, even at the new foundations) would bring some financial benefit upon graduation. The problem, then, was that most of the professions were still far from convinced of the value of the courses that the new institutions offered and until the middle of the nineteenth century, the links between industry and the universities were negligible. ${ }^{37}$

The earliest profession to recognise the need and importance of higher education were the medics, but they were driven to do so at least in part by successive governments legislating in this area. Nevertheless, it was in the 1870s that a combination of increased requirements for formal qualifications and a full acceptance of the scientific ideal led to the amalgamation of local medical schools and nascent universities. ${ }^{38}$ It is therefore unsurprising that medical schools often proved vital — even perhaps the most important part—of the new institutions. While the medical school in Newcastle was founded at about the same time as the University in Durham and did not affiliate with the University until the 1850s, it had been conspicuously more successful than the institution it connected with as it benefited from these changes. What made Durham the senior partner was its ability to award degrees, not its relative vibrancy or achievement.

Similarly, the Church needed more clergy, and the demand was met by the creation of new theological colleges to produce them: starting with St Bees in Cumbria, St David's in Wales and then progressing with new foundations throughout the century. The training of teachers was invigorated by the Education Act of 1870, which saw the expansion of the education colleges in Durham and elsewhere to meet the staffing needs of new and expanded

\footnotetext{
${ }^{30}$ T. Hinde, A Great Day School in London: A History of King’s College School (London, 1995), p. 19; Whyte, Redbrick, p. 47.

${ }^{31}$ Armytage, English Education, pp. 103-6.

${ }^{32}$ Rothblatt, 'Historical and Comparative Remarks', p. 166.

${ }^{33}$ M. Sanderson, Educational Opportunity and Social Change in England (London, 1987), p. 25.

${ }^{34}$ Anderson, European Universities, p. 125.

${ }^{35}$ Rothblatt, 'Historical and Comparative Remarks', p. 166.

${ }^{36}$ Whyte, Redbrick, pp. 42-44.

${ }^{37}$ Sanderson, The Universities and British Industry, p. 3.

${ }^{38}$ Bonner, Becoming a Physician, pp. 259-64.
} 
schools. ${ }^{39}$ Other professions, such as architecture and law, moved more slowly in integrating their professional education needs with the provision of the universities and colleges.

Early in the nineteenth century, engineering was one profession that the new institutions expected to be able to contribute to, and they felt they were acting not only to meet a general demand for better trained professionals, but alongside leading industrialists. Unfortunately for the colleges, most engineering firms preferred the traditional model of paid apprenticeships, which meant that the college graduates gained little or no benefit from their studies ${ }^{40}$ This was one of the most important causes of the collapse of Durham's course in civil engineering. Other engineering courses, including that at King's College, might have survived, but they hardly prospered. The professional education supplied by courses aimed at specific vocations or trades-no matter how lucrative or intellectually demanding the occupation might be-also paled in prestige next to the liberal arts, which remained at the pinnacle of learning, for while it may have been desirable for a medic to be skilled in his profession, for example, he could not be a gentleman without the intellectual training of the liberal arts. Until late into the nineteenth century, it remained the case that the traditional or liberal professions of medicine, law and the Church were united by their common acceptance of the vital importance of a unifying liberal education.

In general, and in addition to these concerns, it was also crucial to the new institutions' disadvantage that English society still operated by patronage and that such support remained important until well into the nineteenth century, with change only starting in about the $1850 \mathrm{~s}^{42}$ The implication of this was that for as long as the support of a prominent patron remained more important than qualifications (and even ability) in order to gain entry to the more desirable careers and professions, the practical value of the system of certificates, degrees and other awards being developed in the new universities and colleges would be minimal. It was only when competition triumphed that the type of education which the new universities and colleges had been created to provide became a desirable route into well-remunerated and respectable occupations. This change happened towards the latter part of the century, when examinations for key professions gave a new impetus for students to resort to the universities when they had not hitherto felt any need to do so; a key example was the establishment of examinations for entry to the Indian Civil Service from 1858, followed by individual departments of the Home Civil Service until 1870, when almost all branches of the Home Civil Service appointed by competitive entry. ${ }^{43}$ There was a distinction between a belief in the type of competitive test of a general and liberal education that drove men like Charles Trevelyan and Stafford Northcote (heavily influenced by Benjamin Jowett) and the reform of the civil service entrance examinations, on the one hand, and the specialised qualifying examinations that developed in medicine and later in other professions, on the other. But where there was a connection between these two approaches was the desire for some form of learning to be assessed impartially and for that test to become the gatekeeper to professional preferment, rather than connections and patronage. ${ }^{45}$ The alignment of a liberal education with the tests required of entry to the civil service nevertheless served to increase the relevance of the universities, and especially of Oxford and Cambridge. Ironically, it also served to make a liberal education a vocational training in the specific case of the civil service. ${ }^{46}$ Between 1855 and 1864 , for example, of the 458 men who entered the Indian Civil Service through competitive examination 22\% came from Oxford and 18\% from Cambridge, and only 17\% came from no university at all. ${ }^{47}$ Between 1892 and 1894, the majority of entrants (52\%) came from Oxford, while a further $20 \%$ came from Cambridge. ${ }^{48}$ The demand for relevant educational preparation also went hand in hand with the growth of the emerging professions. There were, for example, estimated to be only 853 civil engineers in 1841, but by 1881, this had risen to 7124 . The number of civil engineers rose by $183 \%$ between 1841 and 1851 alone, and again by 57\% between 1861 and $1871 .^{49}$ Although even by 1900 formal qualifications were still unnecessary to serve as an engineer, it was the new universities and colleges, and the universities of Scotland, which embraced technologically relevant studies, as well as medicine, and the sciences. Progress with such modern and professional studies remained painfully slow at the ancient English universities. Alongside the more general entrance examination for the civil service, this tended to reinforce the

\footnotetext{
${ }^{39}$ Armytage, Four Hundred Years of English Education, pp. 156-59; Lawrence, St Hild's College, pp. 26-28; G.J. White, On Chester On: A History of Chester College and the University of Chester (Chester, 2014), pp. 3-4, 23-24; and Wilkinson, 'The Durham Diocesan Training School for Masters', pp. 217-18.

${ }^{40}$ Reader, Professional Men, pp. 117-18.

${ }^{41}$ Reader, Professional Men, pp. 10-11, 16-23.

${ }^{42}$ Reader, Professional Men, pp. 4-6; Runciman, Very Different, But Much the Same, pp. 35-40.

${ }^{43}$ Armytage, English Education, p. 121; Reader, Professional Men, pp. 90-96; Roach, Public Examinations, pp. 191-228; and Vernon, Universities and the State in England, p. 47.

${ }^{44}$ Report on the Organisation of the Permanent Civil Service Together with a Letter from the Rev. B. Jowett (London, 1854).

${ }^{45}$ Reader, Professional Men, p. 86.

${ }^{46}$ Sanderson, Universities and British Industry, p. 6.

${ }^{47}$ Reader, Professional Men, p. 93.

${ }^{48}$ Vernon, Universities and the State in England, p. 47.

${ }^{49}$ Reader, Professional Men, pp. 208-11.
} 
distinction between Oxford and Cambridge as more prestigious, glamorous and powerful than the new universities and colleges.

Towards the end of the nineteenth century, a convergence of factors created a significantly more benign environment for expansion in the new universities and colleges: the growth in secondary education created a larger pool of potential applicants and the ability to concentrate on higher (rather than secondary) education; patronage declined in favour of more meritocratic means of gaining professional preferment; and the professions gradually formalised and, although reluctant at first, started to align themselves with higher education. By about the 1870s, therefore, there was a more demonstrable need for the increased provision of higher education in England (especially from the growing middle classes) that had not existed at the start of the century. ${ }^{51}$ Writing in 1878, Adolphus Ward, Professor of History and English Literature at Owens College, argued that there was a 'growing demand for academical instruction' which had been brought about as the 'old studies' had 'become wider and fuller'. The demand had also been fed by the development of 'New Learning, like the Renascence Age ... such as medicine, and various branches of physical and mechanical science'. Although he was far from impartial, Ward could still argue with conviction that 'a carefully considered and prudently carried-out increase in the number of English universities is expedient and indeed necessary'. 52

Ward's argument made 20 years earlier would have been unsustain- able, given the parlous state of the new universities then struggling for existence. The growing demand for higher education was by this point sufficiently clear that Victoria University was established in 1880 as a federal institution. As with University of London in 1836, the federal structure was again used as a compromise due to concerns from competing rival colleges in the north that they would be unable to compete with the attractions of a degree-awarding university in Manchester. While Owens College was the first and to start with the only constituent college of the new Victoria University in 1880, University College Liverpool was admitted in 1884 and the Yorkshire College in Leeds was admitted in $1887^{53}$

A similar structure was adopted for the University of Wales in 1893, which affiliated the university colleges in Aberystwyth, Bangor and Cardiff. ${ }^{54}$ However, even in the late 1870 s, the new institutions were far from secure. King's College especially felt the impact of these new federal institutions in the north of England and Wales. From the mid1880s, the finances at the College collapsed, along with dwindling student numbers. While a small surplus was returned in 1884, for the next ten years the accounts showed a deficit of never less than $£ 1000$ and up to almost $£ 8000$ in 1895. Income from student fees sank from $£ 34,775$ in 1881 to $£ 27,485$ in 1891; in 1893, there were only ten students in the Department of general literature and science, a lower point than Durham ever reached. ${ }^{55}$

\section{The resurgence of Oxford and Cambridge}

Yet while such advantages that came with broader changes in education and society by the 1870 s only served to make the task of the new institutions more viable, they did not remove all the barriers that these institutions faced. Perhaps the greatest of those barriers was the resurgence of Oxford and Cambridge.

This revised political order from the 1820s onwards created increasing tension for the Universities of Oxford and Cambridge. The impact of the reforming Acts was to include Dissenters and Catholics within the broader political nation. Political and government positions had now been opened up. Yet the ancient English universities continued their practice of exclusion, preventing students from graduating at Cambridge or even matriculating at Oxford. ${ }^{56}$

Although both institutions seemed constantly behind when it came to reform and the advancement of new and professional studies, still they managed to secure and retain the greatest amount of prestige in higher education. Nevertheless, the transformation they went through is also easy to under-estimate. ${ }^{57}$ Writing in 1898 , for example, the author of the history of Trinity College, Oxford noted that the changes were 'so great that the first half of the century is almost ancient history, though some of it is within living memory'. ${ }^{58}$ The creation of the new colleges and universities actually encouraged reform at Oxford and Cambridge; with- out competition for several centuries, they had fallen into some measure of complacency, but the new institutions threatened to overtake them if they did not

\footnotetext{
${ }^{50}$ Reader, Professional Men, pp. 127-45.

${ }^{51}$ Anderson, Universities and Elites, pp. 31-41.

${ }^{52}$ A.W. Ward, 'Is it Expedient to Increase the Number of Universities in England?', Macmillans’ Magazine, 39(229) (1878), pp. 12-16, at p. 13.

53 Jones, Origins of Civic Universities, pp. 161-65.

${ }^{54}$ Anderson, British Universities Past and Present, pp. 93-95; Armytage, Civic Universities, pp. 36-38.

${ }^{55}$ Hearnshaw, King's College London, pp. 353-55.

${ }^{56}$ Brent, Liberal Anglican Politics, pp. 184-85.

${ }^{57}$ Winstanley, Early Victorian Cambridge, pp. 174-75.

${ }^{58}$ H.E.D. Blakiston, University of Oxford College Histories: Trinity College (London, 1898), p. 213.
} 
reform. ${ }^{59}$ Even the 1861 Commissioners noted that 'we are not insensible to the operation of recent changes in the Universities of Oxford and Cambridge in drawing away students from the School of Arts at Durham. The emoluments of the Colleges in those Universities have largely increased, the expenses of the students have been diminished, and various restrictions have been removed which formerly fettered the freedom of competition'.

\section{Conclusion}

Durham, London and King's College were founded in the brief period between the indulgences of the eighteenth century and the reforms which would secure the prominence of Oxford and Cambridge into the twentieth century and beyond. By 1831, reform of the ancient universities had commenced, but the outcome of those reforms was far from realised. The resurgence of the ancient English universities following the Commissions of the 1850s therefore further diminished the prospects of the new institutions, as the social status they conferred far outstripped any advantages that the new institutions could offer.

${ }^{59}$ W. Whyte, 'Redbrick’s Unlovely Quadrangles: Reinterpreting the Architecture of the Civic Universities', History of Universities, XXI(1) (2006), pp. 151-78, at p. 161.

${ }^{60}$ Report of the Commissioners Appointed for the Purposes of the Durham University Act 1861 (London, 1863$)$, p. 7.

\section{Bibliography}

Anderson, R.D. British Universities Past and Present (London, 2006).

Anderson, R.D. European Universities from the Enlightenment to 1914 (Oxford, 2004).

Anderson, R.D. Universities and Elites in Britain Since 1800 (London, 1992).

Armytage, W.H.G. Civic Universities: Aspects of a British Tradition (London, 1955).

Armytage, W.H.G. Four Hundred Years of English Education, 2nd edn (Cambridge, 1970).

Attar, K.E. “"The Establishment of a First-Class University Library”: The Beginnings of the University of London Library’, History of Universities, XXVIII/1 (2014), pp. 44-65.

Bellot, H.H. University College, London 1826-1926 (London, 1929).

Blakiston, H.E.D. University of Oxford College Histories: Trinity College (London, 1898).

Bonner, T.N. Becoming a Physician: Medical Education in Britain, France, Germany, and the United States, 1750-1945 (London, 1995).

Brent, R. Liberal Anglican Politics: Whiggery, Religion, and Reform 1830-1841 (Oxford, 1987).

Chaloner, W.H. The Movement for the Extension of Owens College Manchester 1863-73 (Manchester, 1973).

Greenwood, M. 'University Education: Its Recent History and Function', Journal of the Royal Statistical Society, 98/2 (1935), pp. 1-33.

Hearnshaw, F.J.C. The Centenary History of King’s College London 1828-1928 (London, 1929).

Hinde, T. A Great Day School in London: A History of King's College School (London, 1995).

Jarausch, K.H. (ed.), The Transformation of Higher Learning 1860-1930 (Chicago, 1983).

Jones, D.R. The Origins of Civic Universities: Manchester, Leeds and Liverpool (London, 1988).

Lawrence, A. St Hild's College 1858-1958 (Darlington, 1958).

Niblett, W.R. (ed.), Higher Education: Demand and Response (London, 1969).

Pietsch, T. Empire of Scholars: Universities, Networks and the British Academic World, 1850-1939 (Manchester, 2013 ).

Reader, W.J. Professional Men: The Rise of the Professional Classes in Nineteenth- Century England (London, 1966).

Report of the Commissioners Appointed for the Purposes of the Durham University Act 1861 (London, 1863$).$

Report on the Organisation of the Permanent Civil Service Together with a Letter from the Rev. B. Jowett (London, 1854).

Roach, J. Public Examinations in England, 1850-1900 (Cambridge, 1971).

Roderick, G.W., and Stephens, M.D. 'Mining Education in England and Wales in the Second Half of the Nineteenth Century', The Irish Journal of Education, 6/2 (1972), pp. 105-20.

Rothblatt, S. 'Historical and Comparative Remarks on the Federal Principle in Higher Education', History of Education, 16/3 (1987), pp. 15180.

Runciman, W.G. Very Different, But Much the Same: The Evolution of English Society Since 1714 (Oxford, 2015).

Sanderson, M. Educational Opportunity and Social Change in England (London, 1987).

Sanderson, M. The Universities and British Industry 1850-1970 (London, 1972).

Simon, B. The Two Nations and the Educational Structure 1780-1870 (London, 1974).

Sutherland, G., et al. (eds.), Education (Dublin, 1977).

Thompson, J. The Owens College: Its Foundation and Growth and Its Connection with the Victoria University, Manchester (Manchester, 1886).

Vernon, K. Universities and the State in England 1850-1939 (London, 2004).

Ward, A.W. 'Is it Expedient to Increase the Number of Universities in England?', Macmillans’ Magazine, 39/229 (1878), $12-16$.

Ward, W.R. Victorian Oxford (London, 1965).

White, G.J. On Chester On: A History of Chester College and the University of Chester (Chester, 2014).

Whiting, C.E. University of Durham 1832-1932 (London, 1932).

Whyte, W. Redbrick: A Social and Architectural History of Britain's Civic Universities (Oxford, 2015).

Whyte, W. 'Redbrick’s Unlovely Quadrangles: Reinterpreting the Architecture of the Civic Universities', History of Universities, XXI/1 (2006), pp. 151-78.

Wilkinson, K.R. 'The Durham Diocesan Training School for Masters 1839-1886’ (Durham University, MEd thesis, 1968).

Winstanley, D.A. Early Victorian Cambridge (Cambridge, 1940). 


\section{List of figures}

Fig. 7.2 Entrants 1837/38-1847/48 (Durham only, Engineering) (Source [DUL] DUR: Admission Book 1833-1896)

Fig. 8.1 Participation rates in English universities 1801-1901 (male students only) (Source Greenwood, 'University Education', p.7)

Fig. 8.2 Entrants to English universities 1799-1903 (male students only) (Source Greenwood, 'University Education', p. 6)

Fig. 8.3 Entrants 1833/34-1842/43 (Durham only, all courses) (Source [DUL] DUR: Admission book 1833-1896)

Fig. 8.4 Entrants 1833/34-1842/43 by course (Durham only) (Source [DUL] DUR: Admission book 1833-1896. Two students are omitted from this table as it was not possible to identify the course they entered to study. In addition, many students progressed from one course to a second course, but these continuing students have been omitted))

Fig. 8.5 Entrants 1843/44-1862/63 (Durham only, all courses) (Source [DUL] DUR: Admission book 1833-1896)

Fig. 8.6 Students 1833/34-1862/63 (Durham only, all courses) (Source As listed in the University Calendar)

Fig. 8.7 Students 1833/34-1862/63, Durham and King's College, London (Arts course) (Source 'Durham (Arts)' as listed in University Calendar. 'KCL (General Arts)' from Hearnshaw, King's College London)

Fig. 10.1 Entrants 1863/64-1875/76 (Durham only, Arts course) (Source [DUL] DUR: Admission Book 1833-96)

Fig. 10.2 Students 1863/64-1875/76, Durham and King's College, London (Arts course) (Source 'Durham (Arts)' as listed in the University Calendar. 'KCL (General Arts)' taken from tables in Hearnshaw, The Centenary History of King's College London)

Fig. 10.3 Entrants 1876/77-1895/96 by previous institution (Durham only, Arts course) (Source [DUL] DUR: Admission Book 1833-1896)

Fig. 10.4 Entrants 1871/72-1890/91 by college or hall (Durham only, all courses) (Source [DUL] DUR: Admission Book 1833-1896) 